\title{
Preoperative and Postoperative Evaluation of Somatosensorial Evoked Potentials of Upper Extremities in Cervical Intervertebral Disc Herniation
}

\author{
Servikal Intervertebral Disk Herniasyonunda Üst Ekstermite \\ Somatosensorial Uyarılmış Potansiyellerinin Preoperatif ve Postoperatif \\ Değerlendirilmesi
}

Ahmet Sukru UMUR ${ }^{1}$, Mehmet SELCUKI ${ }^{1}$, Deniz SELCUKI ${ }^{1}$, Cuneyt TEMIZ ${ }^{1}$, Aytac AKBASAK ${ }^{2}$

${ }^{1}$ Celal Bayar University, Faculty of Medicine, Department of Neurosurgery, Manisa, Turkey

${ }^{2}$ Kafkas University, Faculty of Medicine, Department of Neurosurgery, Kars, Turkey

Corresponding Author: Ahmet Sukru UMUR / E-mail: umuras@yahoo.com

\begin{abstract}
This study aims to determine the dysfunction caused by existing pathological condition in structures involved in the transfer of sensory functions of the neural system in cervical disc herniation, and to establish whether or not the level and degree of this anatomical damage can be anticipated by SEP (Somatosensorial Evoked Potentials).

We compared the obtained SEP values for statistical significance using the Friedman Variation Analysis. In parameters with statistical significance, the Wilcoxon Signed Rank test was used to identify when significant improvements occurred.

The study found that the statistical data of the latency of the N14 wave originating from the dorsal column nuclei of the medulla spinalis and dorsal column gray matter improved $(p<0.05)$ in the postoperative period compared with the preoperative values. Using the Wilcoxon Signed Rank test, we studied postoperative months separately in regard to the difference in the latency of the N14 wave, and found the statistically significant improvement to be marked particularly in months 3 and 6 postoperatively $(p<0.05)$.

In conclusion, we suggest that SEP is a useful tool to check the functional condition of the dorsal spinal column. The benefit of the SEP utilization is the ability to determine the severity of the pathological condition preoperatively and follow the patient's functional postoperative improvement.
\end{abstract}

KEYWORDS: Cervical disc herniation, Somatosensory evoked potentials

öz

Bu çalışmada; servikal disk herniasyonunda, mevcut patolojinin nöronal sistemin duysal fonksiyonlarının iletiminde görev alan yapılarında yarattığı fonksiyonel bozukluğu ve anatomik olarak oluşan bu hasarın düzey ve derecesini SUP ile belirlenebilirliğini saptamayı amaçladık.

Gruplarda Friedman Varyans Analizi kullanılarak, elde edilen SUP değerlerini, istatistiksel olarak anlamlılık açısından karşılaştırdık. Anlamlılık gözlenen parametrelerde Wilcoxon Signed Range Test kullanılarak anlamlılığın hangi aylarda oluştuğunu karşılaştırdık.

Medulla spinalis dorsal kolon nukleusları ve dorsal kolon gri cevherinden kaynaklanan N14 dalgasının latansının preoperatif ve postoperatif dönemde karşılaştırılan verilerinin istatistiksel olarak iyileşme yönünde anlamlılık taşıdığını gördük $(P<0,05)$. N14 dalga latans değişiminde gözlenen anlamlılığın Wilcoxon Signed Range Test kullanılarak hangi aylarda oluştuğunu karşılaştırdık ve bu anlamlılığın postoperatif 6 . ay $(P<0,05)$ ve 3-6. ayda belirgin olduğunu $(P<0,05)$ bulduk.

Sonuç olarak SUP' un medulla spinalis dorsal alanına ait duysal fonksiyon bozukluğunun araştırılmasında yararlı bir testtir. SUP' un kullanımının getireceği yarar; oluşan patolojinin ciddiyetinin saptanması ve operasyondan sonra hastanın gördüğü fonksiyonel iyileşmenin takibinin yapılmasıdır.

ANAHTAR SÖZCÜKLER: Servikal disk herniasyonu, Somatosensorial uyarılmış potansiyeller 


\section{INTRODUCTION}

Somatosensory evoked potentials (SEPs) recorded at cervical cord levels have been intensively studied in recent years. It has been shown that evoked potentials of the spinal cord correspond to activity in the dorsal column pathways $(2,5,7,8,9,10,11,12,16,18)$. Cervical disc disease of the cervical spine is one of the most common causes of cervical myelopathy or radiculopathy $(5,8,9,15)$.

Magnetic resonance imaging (MRI) of the cord can show us several types of signal anomalies at the level of cord compression, but it obviously cannot give information about the cervical cord or radix dysfunction $(9,10)$.

Somatosensory evoked potentials have been used to disclose abnormalities of ascending sensory pathways in cervical disc disease, spondylotic myelopathy and other pathological conditions $(2,7,5,9,10,11)$.

We studied SEPs after stimulation of median nerve in 17 patients with cervical disc disease in order to assess the effectiveness of SEPs in detecting cervical cord or root damage. The recordings of pre and postoperative period were compared with each other after a rather long follow-up period.

\section{MATERIAL and METHODS}

\section{Patients}

This study includes a total of 17 patients who have undergone cervical disc surgery due to cervical disc herniation. 11 of them were female (64.7\%), aged 37-67, with the mean age being 50.8 years. The age range in males was $33-52$ with a mean age of 39.6 years. Preoperative clinical findings of the cases are shown in Table I.

\section{Operative Indications}

The common criterion for the selection is clinical progressive neurological deficit in cases with one or two-level disc herniation in the cervical spine (radiculopathy and/or myelopathy findings). The presence of persistent radicular pain not relievable despite conservative therapy, disc herniation in cervical $\mathrm{MRI}$, and medullar compression symptoms and signs were accepted as indications for operation $(3,6,5)$. Cervical disc surgeries were performed as described by Cloward (14).

One-level discectomy was performed in 9 out of 17 cases and two-level discectomies in 8 patients. Fusion with "cage" was achieved on 14 patients. Cage applications were done at one level on 9 cases and two levels on 5 cases. Soft disc herniation was observed in 13 cases (76.4\%) and calcified disc herniation in 4 cases $(23.6 \%)$. Free epidural disc fragment was found in one case (5.9\%).

\section{SEP Recording Technique}

To determine SEP records, Medelec Sapphire 2E, 2-channel EEG-EMG device was used. Bilateral median SEP values were also recorded for all cases.

\section{Statistical Assessment}

Pre and post-operative first, third and sixth month median SEP values for the upper extremities were assessed on the basis of abnormality criteria described by SpehIman (13). We compared the obtained SEP values for statistical significance using the Friedman Variation Analysis. In parameters with statistical significance, Wilcoxon Signed Range test was used to identify when significant improvements occurred (Table II).

\section{RESULTS}

Clinical assessments of the cases at first postoperative month revealed no persistent radicular pain at previous pain sites in all cases. Radicular sensory loss was still present in 9 cases (52.9\%). Sensory loss was not noted in 8 cases (47.1\%). It was observed that radicular motor weakness was still present in 5 cases $(29.4 \%)$ at follow-up examination in the first postoperative month.

No paravertebral muscle spasms occurred in any of the cases. Hypoactivity in deep tendon reflexes in the preoperative period were not observed in the first post-operative month. Improvement in motor power was observed in 11 patients with pre-operative radiculopathy and myelopathy findings.

In the third month postoperatively, as in the preoperative period, subjective sensory loss was observed in 3 cases $(17.6 \%)$ and muscle power loss in 4 cases $(23.5 \%)$ as in the preoperative period.

At month three, there was continued improvement in muscle power observed in the first month in cases with radiculopathy and myelopathy findings.

In the clinical assessment of the cases at sixth month postoperatively, sensory loss in two cases $(11.7 \%)$ and muscle power loss in one case (5.1\%) still persisted.

\section{Preoperative and Postoperative SEP Findings of the Cases}

Preoperative and, postoperative first, third and sixth month median SEP findings of upper extremities were assessed. We tried to find out whether the latency differences of all parameters, which we have statistically assessed for the median nerve SEP findings of the upper extremities including bilateral findings of bilateral cases, were meaningful in terms of the Friedman variance analysis. Consequently, we observed that the latencies of Erb-cervical (N9-N13), cervicalscalp (N13-N20), brainstem-scalp (N14-N20), Erb-Scalp (N9-N20) and Erb-N9 cervical, cervical- N11, cervical-N13, brainstem-N14, and scalp-N20, scalp-P25 were not statistically meaningful $(p>0.05)$.

Bilateral cases were excluded due to the shortage of participants. We observed that the latency differences of all parameters, except for $\mathrm{N} 14$, were not statistically meaningful $(p>0.05)$.

The study found that the statistical data of the latency of the $\mathrm{N} 14$ wave originating from the dorsal column nuclei of the medulla spinalis was statistically meaningful $(p<0.05)$. 
Table I: Preoperative Clinical Findings of the Cases

\begin{tabular}{|c|c|c|c|c|c|c|c|}
\hline Case & $\begin{array}{l}\text { Duration of } \\
\text { symptoms }\end{array}$ & Pain & $\begin{array}{l}\text { Level of Sensory } \\
\text { Lose }\end{array}$ & $\begin{array}{l}\text { Muscle strength } \\
\text { Absences }\end{array}$ & PMS & Atrophia & Reflex absence \\
\hline 1 & 2 Years & Left & $\mathrm{C7}$ & Elbow extensor muscle groups & + & - & Triceps \\
\hline 2 & 6 Years & Left & $\begin{array}{l}\text { C4 } \\
\text { C6 }\end{array}$ & $\begin{array}{l}\text { Arm abduction } \\
\text { Wrist extensor muscle groups }\end{array}$ & + & - & $\begin{array}{l}\text { Deltoid } \\
\text { Triceps }\end{array}$ \\
\hline 3 & 5 Years & Left & $\mathrm{C7}$ & - & + & - & - \\
\hline 4 & 5 Years & Bilat. SB & C6 & All arm muscles group & + & - & $\begin{array}{c}\text { Deltoid, Biceps } \\
\text { Triceps, } \\
\text { Brachioradial }\end{array}$ \\
\hline 5 & 3 Years & Left & $\mathrm{C} 6$ & - & + & - & - \\
\hline 6 & 9 Months & Left & $\mathrm{C5}$ & Elbow flexor muscle groups & + & - & Biceps \\
\hline 7 & 4 Years & Left & - & Wrist extensor muscle groups & + & - & Triceps \\
\hline 8 & 3 Years & Left & $\begin{array}{l}\mathrm{C} 5 \\
\mathrm{C} 6\end{array}$ & $\begin{array}{l}\text { Elbow flexor muscle groups } \\
\text { Wrist extensor muscle groups }\end{array}$ & + & - & - \\
\hline 9 & 2 Years & Right & $\mathrm{C} 6$ & Wrist extensor muscle groups & + & - & - \\
\hline 10 & 10 Years & $\begin{array}{l}\text { Right/ } \\
\text { Left }\end{array}$ & Bilaterally all arm & Quadriparesia & + & - & $\begin{array}{c}\text { Deltoid, Biceps } \\
\text { Triceps, } \\
\text { Brachioradial } \\
\text { hyperreflexia }\end{array}$ \\
\hline 11 & 4 Years & Right & $\begin{array}{l}\mathrm{C} 6 \\
\mathrm{C} 7\end{array}$ & $\begin{array}{l}\text { Wrist extensor muscle groups } \\
\text { Elbow extensor muscle groups }\end{array}$ & + & - & $\begin{array}{l}\text { Triceps, } \\
\text { Brachioradial }\end{array}$ \\
\hline 12 & 1 Year & $\begin{array}{l}\text { Right/ } \\
\text { Left }\end{array}$ & $\mathrm{C7}$ & Elbow extensor muscle groups & + & - & Triceps \\
\hline 13 & 1 Year & $\begin{array}{l}\text { Right/ } \\
\text { Left }\end{array}$ & $\begin{array}{l}\mathrm{C} 6 \\
\mathrm{C} 8\end{array}$ & $\begin{array}{l}\text { Wrist extensor muscle groups } \\
\text { Fingers flexor muscle groups }\end{array}$ & + & - & - \\
\hline 14 & 8 Months & Right & $\begin{array}{l}\mathrm{C} 6 \\
\mathrm{C} 7\end{array}$ & $\begin{array}{l}\text { Wrist extensor muscle groups } \\
\text { Elbow extensor muscle groups }\end{array}$ & + & - & Brachioradial \\
\hline 15 & 4 Years & $\begin{array}{l}\text { Right/ } \\
\text { Left }\end{array}$ & $\begin{array}{l}\mathrm{C} 6 \\
\mathrm{C} 7\end{array}$ & $\begin{array}{l}\text { Wrist extensor muscle groups } \\
\text { Elbow extensor muscle groups }\end{array}$ & + & - & Brachioradial \\
\hline 16 & 3 Years & Left & $\mathrm{C7}$ & Elbow extensor muscle groups & + & - & - \\
\hline 17 & 2 Months & Left & $\begin{array}{l}\mathrm{C} 6 \\
\mathrm{C} 7\end{array}$ & $\begin{array}{l}\text { Wrist extensor muscle groups } \\
\text { Elbow extensor muscle groups }\end{array}$ & + & - & $\begin{array}{c}\text { Deltoid, Biceps } \\
\text { Triceps } \\
\text { Brachioradial }\end{array}$ \\
\hline
\end{tabular}

PMS: Paravertebral muscle spasm.

Table II: Pre and Postoperative Mean Values of N14 Wave Latencies (Wilcoxon Signed Rank Test)

\begin{tabular}{|l|c|}
\hline Postop Month I N14 - Preop N14 & P \\
\hline Postop Month III N14 -Preop N14 & 0.552 \\
\hline Postop Month VI N14 -Preop N14 & 0.272 \\
\hline Postop Month III N14 - Postop Month I N14 & 0.028 \\
\hline Postop Month VI N14 - Postop Month I N14 & 0.916 \\
\hline Postop Month VI N14 - Postop Month III N14 & 0.196 \\
\hline
\end{tabular}

Using the Wilcoxon Signed Range test, we studied postoperative months separately in regard to the difference in the latency of the N14 wave, and found the statistically significant improvement to be marked particularly at month $6(p<0.05)$ and between months 3 and 6 postoperatively $(p<0.05)$. Latency of N14 wave were much closer to normal values in these time periods (Figure 1).

This improvement demonstrates that neurophysiologic and functional improvement took place in the posterior column functions of the patients in the postoperative period. 


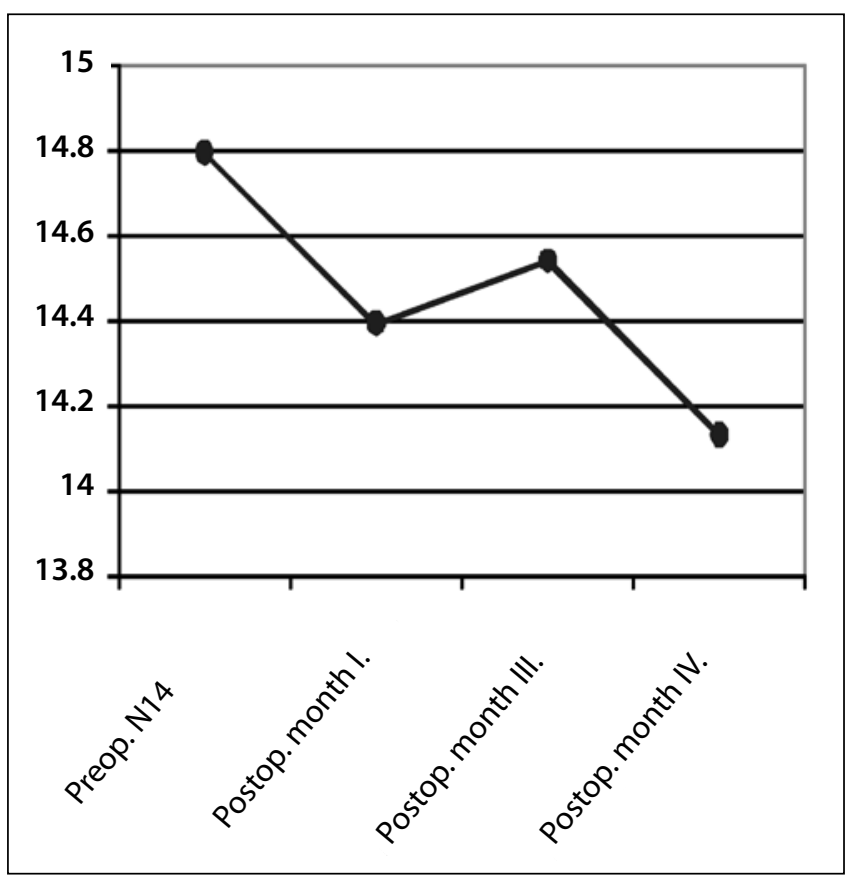

Figure 1: Pre and postoperative mean values of N14 wave latencies.

\section{DISCUSSION}

Somatosensory evoked potentials are used in the assessment of the transfer function of the knowledge of vibration and touch sensation from the peripheral nervous system to the central nervous system $(1,4,13,16,17)$.

Evoked potentials began to appear in neurosurgery literature, including usage in spinal cord operations, in the 1970's. The use of evoked potentials (EP's) in the preoperative, peroperative, and postoperative period started in the 1980's (18).

In the analysis of cervical spondylotic illness, Schram (4) showed in 1980 that it was possible to distinguish radiculopathy and myelopathy through analysis of SEP abnormalities using the simulation technique. It was observed that SEP abnormalities occurred only in the cases of myelopathy, whereas SEP findings within accepted limits and abnormalities of a single dermatome occurred in cases with radiculopathy symptoms. SEP changes were also observed in cervical radiculopathy cases. In addition to the findings of Schram, we also found that such a change could be statistically understandable and meaningful especially at N14 latency changes. We determined on which months such meaningful changes took place as seen in the N14 wave latency by using Wilcoxon Signed Range Test, and observed that this meaningfulness was dominant at month $6(p<0.05)$ and between months 3 and 6 postoperatively $(p<0.05)$. The change in the N14 wave latency was in the form of closeness to normal values compared with preoperative values (Figure 1). This observation showed that functional recovery of patients, as predicted, improved posterior column functions as a result of operative decompression. This is because it was shown that the N13 and N14 waves mainly derived from dorsal column nuclei and gray matter (13). The latency value changes between months 3 and 6 postoperatively seemed as a value to be taken into account in the postoperative period for follow-up examinations.

In 1996, May et al. recorded the SEP values of 26 cases with multi-level, and 16 cases with single-level degenerative disc disease in preoperative, peroperative, and postoperative day 3 time points. Their main emphasis was whether SEP could be a factor of decision-making about surgical intervention and could have a prognostic value in the follow-up period (8). Their results confirmed that SEP results were greatly important and could also be utilized in peroperative monitoring and prognostic tests in the follow-up period.

An important study was reported by Restruccia et al. in 1992 suggesting that the differences of N13 wave latencies could be an evaluation method for subclinically-presented cervical myelopathic patients $(9,10,11)$. They also found that N13 wave latency differences showed dorsal column dysfunction in early phases of degeneration. In their studies, they also indicated that latency delay in N20 potential value was at the rate of $57.9 \%$ and this delay was proportional to the symptoms of the loss of sensation. They also stated that N14 potential delay could be useful in identifying the subclinical damage in dorsal column function. On the other hand, they found that N13 potential change was proportional with reflex deformations. Under the light of this knowledge, they suggested that N13 wave was mainly reflecting the function of medulla spinalis gray matter and latency extension of N13, N14 and N20 potentials formed in cervical myelopathy patients, resembling medulla spinalis dorsal column dysfunction.

It is pointed in many studies that abnormal latency difference of N14 potential in a myelopathic patient is directly proportional with the loss of feeling, regardless of any connection with radiological findings and an indicator of dorsal column compression. We observed a delay in N14 latency, similar with myelopathic patients, in our radiculopathic patients caused by cervical disc herniation $(2,9,10,11)$.

Heiskari et al. identified in a similar study that SEP technique could be utilized functionally in the determination of pressure effects on cervical medulla spinalis or on cervical neural roots (5). In a study analyzing SEP parameters in the preoperative and postoperative periods in 11 spondylotic myelopathy or disc herniation patients, Matsukado et al. pointed out that patients with severe compression evidences determined by SEP both in the preoperative and postoperative periods have become worse in the postoperative period (7). Conclusively, we too observed that statistically significant N14 latencies in SEP findings were parallel with postoperative clinical recovery.

Sloan et al. reported in 1986 that signal changes in cortical SEP wave occurred during anterior cervical surgery, especially during retraction, as a finding that can show the efficacy of SEP monitoring during cervical surgical procedures (12). 
SEP could be used in cervical disc herniation for investigation, in the analysis of sensory loss and dysfunction of medulla spinalis dorsal field that was created by the pressure effect of herniated disc material.

The findings obtained in the preoperative period were not peculiar to the diagnosis of cervical disc herniation. The findings obtained from SEP are useful in diagnosis as they come with clinical and anamnestic findings. It is simple to obtain SEP records, which make such an investigation easy to perform.

\section{CONCLUSION}

We suggest that SEP could be applied as an objective, numerical parameter for the identification of dorsal field ischemia created by the compression of cervical disc herniation. This method of investigation could also be used for detecting the improvement after cervical discectomy operation as a follow-up procedure.

\section{REFERENCES}

1. Daube JR: Clinical Neurophysiology. In: Harper CM: Somatosensory Evoked Potentials. SA. Davis Philadelphia. Chapter 1996:16: 157-170

2. Emerson RG, Pedley TA: Effect of cervical spinal cord lesions on early components of the median nerve somatosensory evoked potentials. Neurology 36: 20-26, 1986

3. Grob D: Surgery in the degenerative cervical spine. Spine 23(24):2674 - 2683, 1998

4. Halliday AM: Evoked potentials in clinical testing. In: Jones SJ: Somatosensorial evoked potentials. The normal and abnormal waveform. 1st ed. NewYork: Churchill Livingstone, 1982:393 - 469

5. Heiskari M, Siivola J, Heikkinen ER: Somatosensory evoked potentials in evaluation of decompressive surgery of cervical spondylosis and herniated disc. Ann Clin Res 18 Suppl (47): 507-513, 1986

6. Matge G: Anterior interbody fusion with the BAK - Cage in cervical spondylosis. Acta Neurochirurgica 140:1 - 8, 1998

7. Matsukado Y, Yoshida M, Goya T, et al: Classification of cervical spondylosis or disc protrusion by preoperative evoked spinal electrogram. Journal of Neurosurgery 44: 435 - 441, 1976
8. May DM, Jones SJ, Crockard HA: Somatosensory evoked potential monitoring in cervical surgery: Identification preand intraoperative risk factors associated with neurological deterioration. J Neurosurgery 85: 566 - 573, 1996

9. Restuccia D, Valeriani M, Lazzaro VD, et al: Somatosensory evoked potentials after upper limb stimulation in diagnosis of cervical spondylotic myelopathy: Journal of Neurology, Neurosurgery and Psychiatry 57(3): 301 - 308, 1994

10. Restuccia D, Lazzaro VD, Monaco M, et al: Somatosensory evoked potentials in the diagnosis of cervical spondylotic myelopathy. Electro - Clin - Neurophysiol 32(7- 8): 389 - 395, 1992

11. Restuccia D, Lazzaro VD, Valeriani $M$, et al: Segmental dysfunction of the cervical cord revealed by abnormalities of the spinal N13 potential in cervical spondylotic myelopathy. Neurology 42: 1054 - 1063, 1992

12. Sloan TB, Ronai AK, Koht A: Reversible loss of somatosensory evoked potentials during anterior cervical spinal fusion. Anesth Analg 65: 96 - 99, 1986

13. Spehlman R: Evoked potential primer, Visual, auditory and somatosensorial evoked potentials in clinical diagnosis: Butterworth Publishers. Part D: 1985:282 - 344

14. Youmans JR (eds), Neurological surgery. In: Ehni B, Ehni G, Patterson RH: Extradural Spinal Cord and Nerve Root Compression from Benign Lesions of the Cervical Area. 3rd ed. Philadelphia: WB Saunders, 1990:2878 - 2917

15. Youmans JR: Neurological surgery. In: Hoff J, Hood T: Anterior Operative Approaches for Benign Cervical Lesions. 3rd ed. Philadelphia: WB Saunders, 1990:2923 - 2936

16. Youmans JR: Neurological surgery. 4/e CD - ROM. In: Makla ME, Friedman WA (eds), Monitoring the Nervous System. 4th ed. Folio Corporation, 1994:4530 - 4936

17. Wilkins RH, Rengachary SS (ed), Neurosurgery. In: Rengachary SS: Examination of the Motor and Sensory System and Reflexes. 2nd ed. New York: Mc Graw Hill 1996:139 - 163

18. Zileli M: Nöroşirürjide Elektrofizyolojik Monitörleme -Teknikleri. Klinik Nörofizyoloji, EEG - EMG Derneği, 1994:44 - 45 